\title{
Colossoma macropomum females can reproduce more than once in the same reproductive period
}

\author{
Luana Barbosa Pires ${ }^{\mathrm{a}, *}$, Ruy Alberto Caetano Corrêa Filho ${ }^{\mathrm{a}}$, \\ Eduardo Antonio Sanches ${ }^{\mathrm{b}, \mathrm{c}}$, Elizabeth Romagosa ${ }^{\mathrm{d}}$, Thiago Gonsalo da Silva ${ }^{\mathrm{e}}$, \\ Silvia Rech ${ }^{\mathrm{e}}$, Danilo Pedro Streit Jr. ${ }^{\mathrm{f}}$, Jayme Aparecido Povh ${ }^{\mathrm{a}}$ \\ ${ }^{a}$ Animal Science Graduate Program, Faculty of Veterinary Medicine and Animal Science, FAMEZ, Federal University of Mato Grosso do Sul - UFMS, \\ Av. Senador Filinto Muller, 2443 - Vila Ipiranga, ZIP 79070-900, Campo Grande, MS, Brazil \\ ${ }^{\mathrm{b}}$ UNESP, Fishery Engineering Program, Registro, SP, Brazil \\ ${ }^{\mathrm{c}}$ CAUNESP, Jaboticabal, SP, Brazil \\ ${ }^{\mathrm{d}}$ Fishery Institute, APTA, SAA, São Paulo, SP, Brazil \\ e Faculty of Veterinary Medicine and Animal Science, FAMEZ, Federal University of Mato Grosso do Sul - UFMS, Av. Senador Filinto Muller, 2443 - \\ Vila Ipiranga, ZIP 79070-900, Campo Grande, MS, Brazil \\ ${ }^{\mathbf{f}}$ Animal Science Research Program, Federal University of Rio Grande do Sul - UFRGS, Av. Bento Gonçalves, 7712, ZIP 91540-000, Porto Alegre, RS, \\ Brazil
}

\section{A R T I C L E I N F O}

\section{Keywords:}

Hormonal induction

Rheophilic

\begin{abstract}
A B S T R A C T
The aim of the present study was to evaluate induced reproduction in Colossoma macropomum females at the beginning of the reproductive period and 75 days after the first spawning in which reproduction was induced. The experiment was conducted in Nova Mutum, MT, Brazil. Eight 4year-old $C$. macropomum females with an average body weight of $6.7 \pm 2.4 \mathrm{~kg}$ were used. Hormonal induction was performed at the beginning of the reproductive period and repeated 75 days after the first spawning. The following variables were then evaluated: weight of released oocytes, production index, absolute fecundity, oocyte diameter, fertilization rate, and hatching rate. Of the eight females that spawned during the first hormonal induction, three $(37.5 \%)$ spawned again 75 days after the first spawning. Two females died after the first induced spawning. None of the means of the evaluated variables differed between the two induced spawnings, except for fertilization rate, which was greater $(P<0.05)$ with the first spawning $(88.8 \pm 6.1 \%)$ than in the second $(74.1 \pm 10.4 \%)$. The results of the present study indicate that C. macropomum females can reproduce again 75 days after a first induced spawning.
\end{abstract}

\section{Introduction}

Colossoma macropomum, commonly known as tambaqui, is the second largest freshwater fish in South America (Goulding and Carvalho, 1982), reaching $40 \mathrm{~kg}$ in weight and $108 \mathrm{~cm}$ in length (Froese and Pauly, 2016). This is a species of great economic importance for several South American countries; in Brazil, its production reached 136,991.5t in 2016 (IBGE, 2018). Colossoma macropomum are recognized among the fish species for its growth rates (Mello et al., 2015), and wide acceptance by consumers as a food source (Gomes et al., 2010).

\footnotetext{
* Corresponding author at: Animal Science Graduate Program, Faculty of Veterinary Medicine and Animal Science, FAMEZ, Federal University of Mato Grosso do Sul - UFMS, Brazil.

E-mail address: luana.bio@hotmail.com (L.B. Pires).
} 
In its natural environment, $C$. macropomum starts reproduction after an increase in the light portion of the photoperiod, temperature, and precipitation, with the greatest spawning activity occurring between November (end of spring) and February (end of summer; Muniz et al., 2008). Reproduction, however, occurs only when the fish ascend the river during the piracema. Rheophilic species such as tambaqui do not reproduce naturally in tanks used for fish-farming, because of the absence of migration which would occur in rivers in their natural habitat and reproductive hormone secretion is not adequate to induce the onset of reproduction in the absence of this migration (Nagahama, 1983). Although the females of reophilic species may have gonadal development when maintained on fish farms, they do not fully mature (Zohar and Mylonas, 2001). The reproduction of tambaqui on fish farms, therefore, occurs only upon hormonal induction during the reproductive period, when environmental conditions (temperature, photoperiod, and rainfall) are favorable (Woynarovich, 1986).

Induced reproduction of $C$. macropomum is performed only once during the reproductive period, which leads to underutilization of fish stocks. Using females more than once during the reproductive season can maximize fingerling production by breeders of fish with greater genetic potential. There, however, are no scientific reports indicating the possibility of tambaqui (a species characterized by synchronous gonadal development) spawning twice in the same reproductive period. This is an important aspect to maximize fingerling production in the farming of fish with relatively greater genetic value, as is the case of those originating from the $C$. macropomum breeding program under development in Brazil (Marcos et al., 2016).

Studies on reproduction in C. macropomum have focused on cryopreservation of gametes (Varela et al., 2012), cooling of embryos (Pessoa et al., 2013), evaluation of different hormonal inducing regimens (Martins et al., 2017), adequate inseminating doses (Leite et al., 2013), assessment of gamete quality (Maria et al., 2010), and successive semen collections (Pires et al., 2017). There, however, is no scientific information on successive oocyte collections in $C$. macropomum in the same reproductive period. The aim of the present study was to evaluate induced reproduction in Colossoma macropomum females at the beginning of the reproductive period and 75 days after the first spawning.

\section{Material and methods}

The experiment was conducted on a fish farm in the municipality of Nova Mutum, Mato Grosso, Brazil (13 $51^{\prime} 57.2^{\prime \prime} \mathrm{S}$ and $56^{\circ} 11^{\prime} 30.2^{\prime \prime} \mathrm{W}$ ). The first hormonal induction was performed at the beginning of the reproductive period (October 2016) and repeated 75 days after the first spawning (December 2016). This study was approved by the Ethics Committee of the Federal University of Mato Grosso do Sul, Brazil (approval no. 643/2014).

Eight 4-year-old C. macropomum females (originating from broodstock captured in nature) with an average body weight of $6.7 \pm 2.4 \mathrm{~kg}$ were used in the present study. The fish were kept in an excavated tank $\left(500 \mathrm{~m}^{2}\right)$ at the density of 0.2 fish $/ \mathrm{m}^{2}$, with a daily water replacement rate of $10 \%$. The average temperature in the tanks was $28 \pm 2{ }^{\circ} \mathrm{C}$. In the period preceding reproduction, the fish received extruded feed ( $92.6 \%$ dry matter, $28.0 \%$ crude protein, $13.4 \%$ mineral matter, $4.5 \%$ ether extract, and $4.3 \%$ crude fiber) equivalent to $1 \%$ of their body weight per day. After the first spawning, the fish were allocated to an excavated tank $\left(200 \mathrm{~m}^{2}\right)$. The same feeding management was provided to all fish in the period prior to the two spawnings.

Females were selected for reproduction by analyzing their external characteristics, such as erythematous coloration, edema-like appearance of the urogenital papilla, and bulging abdomen (Zaniboni Filho and Weingartner, 2007). In addition, oocytes were collected by intraovarian cannulation (Romagosa et al., 1990), and then placed in Serra's solution (60\% ethanol, 30\% formaldehyde, and $10 \%$ glacial acetic acid) for 3 min (Brzuska, 1979). Only the females with greater than $50 \%$ of oocytes with their germinal vesicles displaced from the center were considered suitable for reproduction (Romagosa et al., 1990). One hundred oocytes per female were collected and preserved in Gilson's solution ( $100 \mathrm{~mL} 60 \%$ alcohol, $880 \mathrm{~mL}$ distilled water, $15 \mathrm{~mL} 80 \%$ nitric acid, $20 \mathrm{~g}$ mercury bichloride, and $18 \mathrm{~mL}$ glacial acetic acid) to measure the diameter (Simpson, 1951).

The selected females were then transferred to masonry tanks $\left(4.0 \mathrm{~m}^{3}\right.$ ) in the laboratory with $10 \mathrm{~L} / \mathrm{s}$ water renewal (average temperature $28 \pm 2{ }^{\circ} \mathrm{C}$ ), where they were weighed and then microchipped. The females were subjected to hormonal induction using carp pituitary extract at $5.5 \mathrm{mg} / \mathrm{kg}$ body weight in two doses: $10 \%$ at first, and the remaining $90 \%$ after $12 \mathrm{~h}$ (Woynarovich and Horváth, 1983; Maria et al., 2012). The males selected for the analyses of fertilization and hatching rates were induced with a single dose of carp pituitary extract of $2.5 \mathrm{mg} / \mathrm{kg}$ body weight (Streit et al., 2005), at the same time as the females. For the second spawning, the fish received the same induced-reproduction protocol and were maintained in the same storage and management conditions.

The fish were anesthetized with eugenol $(50 \mathrm{mg} / \mathrm{L})$ to collect their gametes. Oocytes were collected as described by Woynarovich and Horváth (1983) and Caneppele et al. (2009), while semen was collected according to the method described by Sanches et al. (2011). The gametes were collected after 240 degree - hours following the second injection (Gomes et al., 2010).

After the collection of gametes, artificial fertilization was performed using three oocyte samples $(1 \mathrm{~g}$ each) per female. The individual samples were mixed with a freshly prepared semen pool containing semen of three males (0.12 mL for each 1-g sample). Samples were then placed on a $1-\mathrm{mm}$ sieve and incubated in a cylindrical-conicalincubator (water temperature: $28 \pm 2{ }^{\circ} \mathrm{C}$; water flow: $7 \mathrm{~L} / \mathrm{min})$.

The reproductive variables evaluated included oocyte weight $(\mathrm{g})$, production index (total weight of released oocytes in $\mathrm{g} / \mathrm{animal}$ weight in $g \times 100$ ), absolute fecundity (number of oocytes released during spawning), oocyte diameter (mm), fertilization rate (\% of fertilized eggs), and hatching rate (\% of hatched larvae). The number of oocytes released per female was calculated as the weight of oocytes released multiplied by the average oocyte count of the three 1-g samples. Fertilization rate was estimated $8 \mathrm{~h}$ after the commencement of egg hydration (blastopore closure stage), while hatching rate was estimated shortly after larval hatching (15-20 $\mathrm{h}$ after fertilization; Leite et al., 2013). Oocyte diameter, fertilization rate, and hatching rate were variables that were assessed as the average of three 1-g oocyte samples from each female. These variables were valid for both the first and second spawnings. 


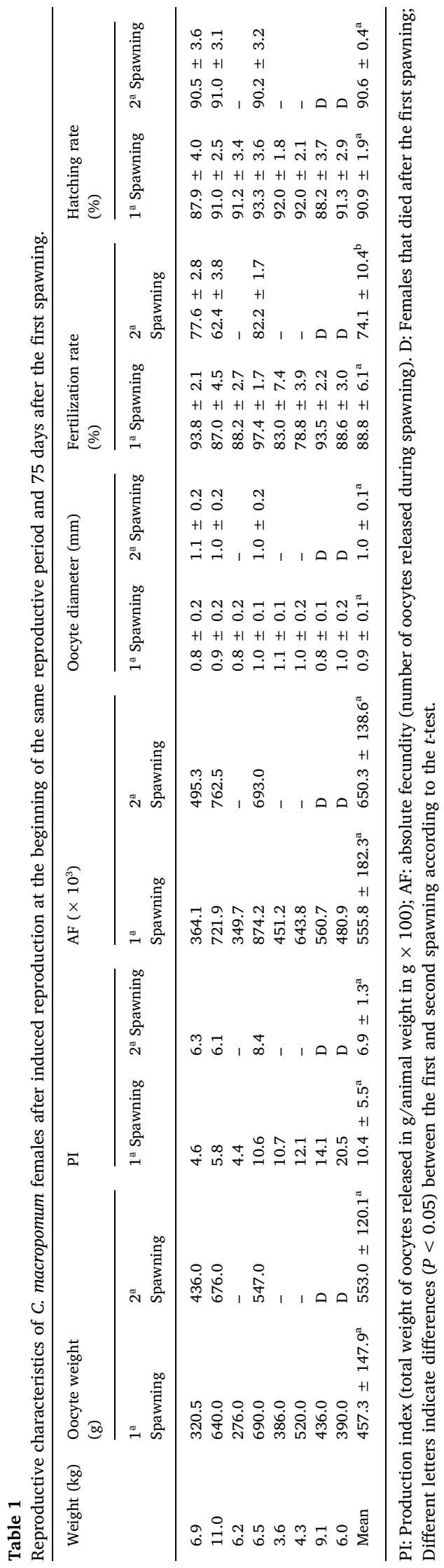


The data were evaluated by applying the Generalized Linear Models procedure of SAS software (Statistical Analysis System) version 9.2. Mean values between the first and second spawnings were compared by the $t$-test at the $5 \%$ probability level.

\section{Results}

Eight females spawned after the first hormonal induction at the beginning of the reproductive period (October 2016). Of these, three females (37.5\%) spawned again 75 days (December 2016) after the first spawning; three females (37.5\%) did not spawn again after 75 days (December 2016); and two females (25.0\%) died soon after the first spawning (Table 1).

The average oocyte weight in the first spawning was not different from that observed in the second spawning (75 days after the first). Likewise, production index, absolute fecundity, and oocyte diameter did not differ between the two spawnings (Table 1).

Fertilization rate was greater $(P<0.05)$ in the first than in the second spawning. Hatching rate, however, did not differ between the two spawnings (Table 1).

\section{Discussion}

In its natural environment, the species C. macropomum has synchronous gonadal development, with one single spawning occurring in the reproductive period. The present study is the first to report successive spawning in $C$. macropomum females in the same reproductive period. The results revealed that $37.5 \%$ of the females spawned again 75 days after the first spawning. This proves that reproductive return in $C$. macropomum females in the same reproductive period is possible. This component of the reproductive pattern has not been exploited in fish reared on fish farms where females reproduce only once a year. Some modifications during hormonal induction can increase the percentage of females that can spawn twice in the same reproductive period. Thus, these results reveal that it is possible to have successive oocyte collections in the same reproductive period, similar to successive semen collections in C. macropomum (Pires et al., 2017).

Although there were two successive oocyte collections with a 75-day interval in the same reproductive period, $25 \%$ of the females died after the first spawning, in the present study. This reinforces the need to improve reproductive protocols using new hormonal inducers (currently, only carp pituitary extract is being used in C. macropomum females) and different hormone doses and/or intervals between doses. It should be emphasized that different hormonal inducers have been successfully evaluated in $C$. macropomum males (Martins et al., 2017) and females (Souza et al., 2018), but there are no reports on effects on the survival of fish in comparison with the traditional protocol involving carp pituitary extract.

The similar means between the two spawnings for the variables of total oocyte weight, production index, and absolute fecundity indicate that oocyte production was not reduced at the second spawning. The total oocyte weight and production index obtained in both the first and second spawnings were similar to those reported by Souza et al. (2018) in a single spawning of $C$. macropomum. There was a greater total oocyte weight (Galo et al., 2015) and absolute fecundity (Vieira et al., 1999) with females that had greater body weights, but without great changes in production index (ratio between oocyte weight and fish weight), as demonstrated in the study of Galo et al. (2015).

The number of oocytes released provides evidence about the reproductive potential of females (Laine and Rajasilta, 1998). Two successive spawnings, therefore, can increase the reproductive potential of females. In the present study, there was an increase in total oocyte number in the females that spawned twice when compared with that of the females that spawned only once. The results also revealed that it is possible to double the production of oocytes with two spawnings in the same reproductive period (75 days after the first spawning). This opportunity, however, has not been exploited in fish farming. Successive reproduction inductions can be implemented to maximize fingerling production of females with greater genetic potential. This is an important aspect to be considered in the current development of the $C$. macropomum selective-breeding program.

In the present study, oocyte diameter in the first $(0.8-1.1 \mathrm{~mm})$ and second $(1.0-1.1 \mathrm{~mm})$ spawnings were similar to those observed in Piaractus mesopotamicus (1.0-1.1 mm) and C. macropomum (0.7-0.9 mm) by Romagosa et al. (1990) and Chellappa et al. (1996), respectively. This finding indicates that the oocytes reached an adequate size for reproduction during both the first and second spawnings, suggesting that the interval between spawnings did not lead to alterations in oocyte diameter.

The lesser fertilization rate in the second spawning (average $74.1 \pm 10.4 \%$ ) compared with the first (average $88.8 \pm 6.1 \%$ ) indicated the necessity to modify regimens of reproductive management and provide different nutritional supplementation to the females, especially after the first spawning. Further, it highlights the need for an adequate recovery period between the first and second spawnings, because stress is one of the factors that can affect reproduction (Small, 2004). Nevertheless, Galo et al. (2015) and Chellappa et al. (1996) obtained fertilization rates of $86.3 \%$ and $80 \%$, respectively, in a single spawning of $C$. macropomum, which are similar to those that resulted in the present experiment. In addition, the hatching rates in the present study (in both the first and second spawnings) were similar to the $89 \%$ rate that was observed by Galo et al. (2015) in a single spawning of C. macropomum.

The use of high-quality fish gametes is important for fertilization and, consequently, for the development of normal embryos (Bromage and Roberts, 1995; Bobe and Labbé, 2010). Although a greater fertilization rate was observed during the first spawning, the oocytes obtained during the second spawning were of good quality, as indicated by a hatching rate that was similar to that observed at the first spawning.

\section{Conclusion}

Colossoma macropomum can reproduce 75 days after the first spawning, producing viable gametes and larvae. 


\section{Acknowledgments}

I wish to thank the Coordination for the Improvement of Higher Education Personnel (CAPES); the Foundation for the Support of the Development of Education, Science and Technology of the State of Mato Grosso do Sul (FUNDECT); and the Buriti Fish Farm in MT, Brazil, for supporting this research.

\section{References}

Bobe, J., Labbé, C., 2010. Egg and sperm quality in fish. Gen. Comp. Endocr. 165, 535-548.

Bromage, N.R., Roberts, R.J., 1995. Broodstock Management and Egg and Larval Quality. Blackwell Science, Oxford.

Brzuska, E., 1979. The in vivo method of estimating the stages of oocyte maturation in carp (Cyprinus carpio L.). Acta Hydrobiol. 21, 423-433.

Caneppele, D., Honji, R.M., Hilsdorf, A.W., Moreira, R.G., 2009. Induced spawning of the endangered Neotropical species Steindachneridion parahybae (Siluriformes: Pimelodidae). Neotrop. Ichthyol. 7, 759-762.

Chellappa, S., Cacho, M.S.R.F., Humtingford, F.A., Beveridge, M.C.M., 1996. Observations on induced breeding of the Amazonian fish tambaqui, Colossoma macropomum (Cuvier) using CPE and HCG treatments. Aquac. Res. 27, 91-94.

Froese, R., Pauly, D., 2016. Fishbase: Colossoma macropomum (Cuvier, 1818). (Accessed 03 September 2017). http://www.fishbase.se/summary/Colossomamacropomum.html.

Galo, J.M., Ribeiro, R.P., Streit Jr., D.P., Albuquerque, D.M., Fornari, D.C., Roma, C.F.C., Guerreiro, L.R.J., 2015. Oocyte quality of tambaqui (Colossoma macropomum) during the reproductive season. Braz. J. Biol. 75, 279-284.

Gomes, L.C., Simões, L.N., Araujo-Lima, C.A.R.M., 2010. Tambaqui (Colossoma macropomum). In: Baldisserotto, B., Gomes, L.C. (Eds.), Espécies Nativas Para Piscicultura No Brasil. UFSM, Santa Maria, pp. 175-204.

Goulding, M., Carvalho, L.C., 1982. Life history and management of the tambaqui (Colossoma macropomum, Characidae) an important Amazon food fish. Rev. Bras. Zool. 1, 107-133.

IBGE, 2018. Produção de aquicultura. (Accessed 20 June 2018). http://www.sidra.ibge.gov.br/bda/tabela/listabl.asp?c $=3940 \& z=t \& o=21$.

Laine, P., Rajasilta, M., 1998. Changes in the reproductive properties of Baltic herring females during the spawning season. Fish. Res. 36, 67-73.

Leite, L.V., Melo, M.A.P., Oliveira, F.C.E., Pinheiro, J.P.S., Campello, C.C., Nunes, J.F., Salmito-Vanderley, C.S.B., 2013. Determination of insemination dose and embryonic development in the artificial fertilization of tambaqui (Colossoma macropomum). Arq. Bras. Med. Vet. Zootec. 65, $421-429$.

Marcos, R., Povh, J.A., Fornari, D.C., Oliveira, C.A.L., Ribeiro, R.P., Lopera-Barrero, N.M., Corrêa Filho, R.A.C., Abreu, J.S., Murari, P.J.F., 2016. Weight gain and morphometric growth of genetically improved tambaqui (Colossoma macropomum). Semina: Ciênc. Agrár. 37, 2521-2528.

Maria, A.N., Azevedo, H.C., Santos, J.P., Silva, C.A., Carneiro, P.C.F., 2010. Semen characterization and sperm structure of the Amazon tambaqui Colossoma macropomum. J. Appl. Ichthyol. 26, 779-783.

Maria, A.N., Azevedo, H.C., Santos, J.P., Carneiro, P.C.F., 2012. Hormonal induction and semen characteristics of tambaqui Colossoma macropomum. Zygote 20, 39-43.

Martins, E.F.F., Streit Junior, D.P., Abreu, J.S., Correa Filho, R.A., Oliveira, C.A.L., Lopera Barrero, N.M., Povh, J.A., 2017. Ovopel and carp pituitary extract for the reproductive induction of Colossoma macropomum males. Theriogenology 98, 57-61.

Mello, F., Oliveira, C.A.L., Ribeiro, R.P., Resende, E.K., Povh, J.A., Fornari, D.C., Barreto, R.V., McManus, C., Streit Junior, D., 2015. Growth curve by Gompertz nonlinear regression model in female and males in tambaqui (Colossoma macropomum). An. Acad. Bras. Ciênc. 87, $2309-2315$.

Muniz, J.A.S.M., Catanho, M.T.J., Santos, J.G., 2008. Influência do fotoperíodo na reprodução induzida do tambaqui, Colossoma macropomum (CUVIER, 1818). Bol. Inst. Pesca. 34, 205-211.

Nagahama, Y., 1983. The functional morphology of teleost gonads. Fish Physiol. 9, 223-275.

Pessoa, N.O., Evangelista, J.S.A., Souza Filho, F.G.M., Souza, M.L.N.M., Arthur, V.L., Sampaio, C.M.S., 2013. Chilling of tambaqui (Colossoma macropomum) embryos at different times of storage. Rev. Bras. Hig. San. Anim. 7, 323-344.

Pires, L.B., Sanches, E.A., Romagosa, E., Corrêa Filho, R.A.C., Streit Jr., D.P., Nass, R.A.R., Povh, J.A., 2017. Semen characteristics of Colossoma macropomum from three successive sample collections in the same reproductive cycle. Aquac. Res. 48, 1-7.

Romagosa, E., Paiva, P., Godinho, H.M., 1990. Pattern of oocytes diameter frequency distribution in females of Piaractus mesopotamicus (Holmberg 1887) (=Colossoma mitrei Berg 1895) induced to spawning. Aquaculture 86, 105-110.

Sanches, E.A., Neumann, G., Baggio, D.M., Bombardelli, R.A., Piana, P.A., Romagosa, E., 2011. Time and temperature on the storage of oocytes from jundiá catfish, Rhamdia quelen. Aquaculture 319, 453-458.

Simpson, A.C., 1951. The Fecundity of the Plaice. Fishery Invest, London.

Small, B.C., 2004. Effect of dietary cortisol administration on growth and reproductive success of channel catfish. J. Fish Biol. 64, 589-596.

Souza, F.N., Martins, E.F.F., Corrêa Filho, R.A.C., Abreu, J.S., Pires, L.B., Streit Jr., D.P., Lopera-Barrero, N.M., Povh, J.A., 2018. Ovopel ${ }^{\circ}$ and carp pituitary extract for induction of reproduction in Colossoma macropomum females. Anim. Reprod. Sci. 195, 53-57.

Streit Jr., D.P., Moraes, G.V., Ribeiro, R.P., Sakaguty, E.S., Povh, J.A., Moreira, H.L.M., 2005. Effects of three different sources of pituitary extract on gonadal inducer in male and female pacu (Piaractus mesopotamicus. Acta Sci. Anim. Sci. 27, 439-447.

Varela Jr., A.S., Corcini, C.D., Gheller, S.M.M., Jardim, R.D., Lucia Junior, T., Streit Junior, D.P., Figueiredo, M.R.C., 2012. Use of amides as cryoprotectants in extenders for frozen sperm of tambaqui, Colossoma macropomum. Theriogenology 78, 244-251.

Vieira, E.F., Isaac, V.J., Fabre, N.N., 1999. Biologia reprodutiva do tambaqui, Colossoma macropomum Cuvier, 1818 (Teleostei, Serrasalmidae), no baixo amazonas, Brasil. Acta Amazônica 29, 625-638.

Woynarovich, E., 1986. Tambaqui e pirapitinga: propagação artificial e criação de alevinos. CODEVASF, Brasília.

Woynarovich, E., Horváth, L., 1983. A propagação artificial de peixes de água tropicais: Manual de extensão. FAO/CODEVASF/CNPq, Brasília.

Zaniboni Filho, E., Weingartner, M., 2007. Induced breeding in migratory fishes. Ver. Bras. Reprod. Anim. 31, 367-373.

Zohar, Y., Mylonas, C.C., 2001. Endocrine manipulations of spawning in cultured fish: from hormones to genes. Aquaculture 197, $99-136$. 